\title{
Olive cuttings survival influences with saline water irrigation
}

\begin{abstract}
Salinity stress is a foremost field of logical apprehension as it constraints plant as well as crop productivity. This condition has been advance damaged by social actions. Hence, there is much scientific encumber on researchers to increase crop yield under environmental stress consecutively to manage with the escalating food stress. The abiotic stress as salinity harmfully affects the survival and biomass production. Cuttings of three olive varieties namely Megaron, Chettoi and Arbequina were planted under the utilization of different levels of saline water for irrigation in tunnel to assess their survival. Olive cuttings took more time for survival than other plant cuttings. Saline water irrigation to three olive varieties cuttings showed very minute differences among treatments. Overall, saline water@4 $4 \mathrm{dSm}^{-1}$ showed the highest number (2) in number of cuttings survived followed by saline water@6 $6 \mathrm{dSm}^{-1}$. Control and other saline water application levels showed the similar number of survived olive cuttings. Among olive varieties, Chettoi variety performed better (1.40 olive cuttings) than other two varieties.
\end{abstract}

Keywords: olive varieties, saline water, callus formation, survival, salinity tolerance
Volume 2 Issue 6 - 2018

\author{
Muhammad Arshad Ullah,' Syeda Sana \\ Aamir,' Muhammad Yasir,'2 Summaira Ali' \\ 'National Agricultural Research Centre, Pakistan \\ ${ }^{2}$ Institue of Soil and Environmental Sciences, Faculty of \\ Agriculture, University of Agriculture, Pakistan
}

Correspondence: Muhammad Arshad Ullah, Land Resources Research Institute, National Agricultural Research Centre, Islamabad, Pakistan, 45500, Email arshadullah I965@gmail.com

Received: October 10, 2018 | Published: December 19, 2018

\section{Introduction}

In many ways the less production is caused to diverse abiotic stresses. Restricting crop reductions attributable to different environmental stresses is the foremost area of concern to deal with the mounting food necessities. ${ }^{1}$ The most important abiotic stresses akin to elevated salinity, drought, cold, and heat harmfully affects the endurance, biomass production, and yield of staple food crops up to $70 \% .^{2-7}$ The bad effect of intemperance minerals such as $\mathrm{Na}^{+}$and/or $\mathrm{Cl}^{-}$on plant is known as salt stress. ${ }^{8}$ Soil salinity appeared long before humans and agriculture; yet, the crisis has been arisen by agricultural practices such as irrigation. ${ }^{9}$ The most serious limiting factor for crop growth and production is salt stress. According to an estimate of FAO, more than $6 \%$ of the world's land is embellished by salinity. So, salinity stress appears to be a major menace to plant and crop efficiency. Abiotic stresses for instance drought, salinity, submergence, acute temperatures, mineral toxicities, and deficiencies damage crop growth and productivity and intimidate food security of the world..$^{10,11}$ Overall temperatures are predictable to mount among $1.1^{\circ} \mathrm{C}$ and $6.4^{\circ} \mathrm{C}$ in the subsequent century (IPCC, 2007). The augmented temperatures will dislocate weather patterns, causing to expect happening of floods, drought, and salinity. Melting ice caps and glaciers are anticipated to lead an ascend in sea level, ${ }^{12,13}$ that can dangerously influence crop yield in coastal areas due to amplified soil salinity. Global population is escalating at a shocking pace and it is estimated to produce from 6 billion to almost 8.3 billion in $2030 .{ }^{14}$ Devoid of vision in going up arable land owing to urbanization, rapid industrialization, and water scarcity in many populous developing countries of the world, ${ }^{15}$ providing food security for the world population will require at least $57 \%$ increase in food grain production by $2050 .{ }^{16}$ Mounting salinity acceptance of the world's major food crops is an important purpose of plant scientists as the world's population is increasing more rapidly than the area of agricultural land to support it. ${ }^{17}$ Soils are classified as saline when the electrical conductivity (EC) is $4 \mathrm{dSm}^{-1}$ or more, which is the same to about $40 \mathrm{mM} \mathrm{NaCl}$ and creates approximately $0.2 \mathrm{MPa}$ osmotic pressure. ${ }^{18}$
A decrease in water potential is finally quantified salinity stress. Plants defy low water potential in diverse traditions with addition of osmolytes and changing the cell walls properties during creation of protective proteins. ${ }^{19}$ Most commonly used food crops are responsive to salinity effects. ${ }^{20}$ Salinity lessens the pace of leaf development, and closes stomata and thereby decreases photosynthesis, with the soil water insufficiency generated by the osmotic stress. ${ }^{21}$ Upon revelation to soil salinity, plants add poisonous concentrations of $\mathrm{Na}+$ in leaves, which enforce an supplementary restraint to growth by falling the endurance of photosynthetic tissues..$^{22}$ The control of $\mathrm{Na}+$ transport and its valuable elimination from the mesophyll leaves cells is thus an important prerequisite for salinity tolerance. $\mathrm{Na}+$ segregation from leaves is linked with salt tolerance in cereal crops plus rice, ${ }^{23,24}$ durum wheat, ${ }^{25}$ bread wheat, ${ }^{26,27}$ barley, ${ }^{28}$ and its wild relatives, ${ }^{29}$ tall wheatgrass..$^{30}$ The main gears that manage salt tolerance are abridged salt uptake or salt exclusion, enhanced $\mathrm{K}^{+} / \mathrm{Na}^{+}$ratio, tissue tolerance, closure of stomata, positive rule of antioxidant system for protection against reactive oxygen species (ROS), synthesis of osmolytes, water use efficiency (WUE), early flowering, and vital growth to attenuate the salt absorption in plant tissue..$^{31,32}$

The exchanges among root-zone conditions and whole-plant effects to better potential gradients and specific ion concentrations, uptake, and toxicity are mostly convoluted and exceedingly intricate to compute. ${ }^{33,34}$ The capability of some plant species, including olives, to eliminate or sort out specific ions ${ }^{35}$ complicates the relationships between ion toxicity, ion concentration in the external solution, and ion concentration in the plant tissue. Saturated-paste EC (ECe) values databases are used for reporting plant tolerance and responses to salinity. ${ }^{36}$ It has been recommended that normal whole-plant response functions to salinity may be better presented in terms of the $\pi$ of the solution in the growing media than in terms of ion concentration or EC. ${ }^{34}$ Root zone salinity even at relatively low exposure levels reduces water potential and relative leaf water content. ${ }^{37} \mathrm{Cell}$ and tissue culture systems have been considered relevant for selection of plant species tolerant to salinity, drought, and other stresses. ${ }^{38,39}$ Such systems offer 
greater control than in vivo growth conditions. ${ }^{40-43}$ In vitro culture systems allow a precise measurement of growth and response to the imposed treatment. ${ }^{42-46}$ The exact tolerance of cells to salinity stress is not understood although, ${ }^{47,48}$ growth parameters in vitro could reflect the exact tissue response. ${ }^{40-49}$ It has been suggested that whole plant response to salinity is associated with a cellular response, ${ }^{48-50}$ and the response of cultures to in vitro induced stress mimics the in vivo plant exposed to similar stress. ${ }^{42-49}$ There is still a controversial question in the essence of plant cell, callus, or whole plant response to salinity in either way. ${ }^{49,50}$ Osmotic has been modified as a technology to tolerate or adapt to ambient conditions in many plants..$^{51,53}$ This methodology facilitates in the endurance and adaptation processes of stressed plant or tissue cultures. ${ }^{49,51}$ Reduction level indicated, but, significant variation according to the cultivar type and the duration of salt exposure. ${ }^{41-54}$ Secondary salinization causes when soils that once had a low concentration of salt indicating saltier because of irrigation and poor drainage. ${ }^{55}$ Salinity may besides consequence in the decline of soil structure and reduce water holding capacity or aerate. Preferably, farmers must irrigate fields with fresh water in dry regions, other than since the stipulate for fresh water in many other sectors, growers use water with a higher salt content such as ground water, drainage water, or treated waste water. $\mathrm{Na}^{+}, \mathrm{Ca}^{2+}, \mathrm{Mg}^{2+}, \mathrm{Cl}^{-}, \mathrm{SO}_{4}{ }^{2-}$ and $\mathrm{HCO}_{3}{ }^{-}$are cations and anions that caused salinity. ${ }^{56}$

\section{Materials and methods}

The experiment was planned at Land Resources Research Institute, NARC Islamabad during January ---- April, 2018 for investigation the impact of salinity on growth of three months sprouted olive cuttings of 3 olive varieties i.e. Megaron, Chettoi and Arbequina under different levels of saline water in tunnel. Seven levels of saline water Table I Effect of saline water on survival of olive cuttings artificially developed $\left(\mathrm{ECw}=0,4,6,8,10,12\right.$ and $\left.14 \mathrm{dSm}^{-1}\right)$. Saline water was applied after alternate days. Completely randomized design was applied.

\section{Results and discussions}

Cuttings of three olive varieties namely Megaron, Chettoi and Arbequina were planted under the utilization of different levels of saline water for irrigation in tunnel to assess their survival. Olive cuttings took more time for survival than other plant cuttings. Data presented in Table 1 indicated different parameters of olive cuttings survival. Saline water irrigation to three olive varieties cuttings showed very minute differences among treatments. Overall, saline water@ $4 \mathrm{dSm}^{-1}$ showed the highest number (2) in number of cuttings survived followed by saline water@6 $6 \mathrm{dSm}^{-1}$. Salinity is damaging worldwide more farm lands owing to brackish irrigation water, poor drainage, brackish water flooding of coastal land, and salt addition in arid lands. Escalating salinity decreased leaf and shoots growth parameters and augmented the quantity of leaf proline, and leaf and root $\mathrm{Na}^{+}$and $\mathrm{Cl}^{-}$. Gibberellins minimized sodium and chloride concentrations in plants and increased the quantities of potassium and chlorophyll contents. ${ }^{57}$ Gibberellin increased the synthesis and accumulation of proline in two cultivars under different sodium chloride levels, however, this increase was more pronounced in "shiraz". "Shiraz" showed more vegetative growth than "zard and rate of $\mathrm{Na}^{+}$accumulation in leaves and roots was lower in "shiraz" than in "zard". Control and other saline water application levels showed the similar number of survived olive cuttings. Among olive varieties, Chettoi variety performed better (1.40 olive cuttings) than other two varieties. $^{58}$

\begin{tabular}{|c|c|c|c|c|c|c|c|c|c|c|c|c|c|c|c|c|}
\hline \multirow{2}{*}{$\begin{array}{l}\text { Treatment } \\
\text { Varieties }\end{array}$} & \multicolumn{4}{|c|}{$\begin{array}{l}\text { \# of cuttings } \\
\text { survived }\end{array}$} & \multicolumn{4}{|c|}{$\begin{array}{l}\text { \# of survived cuttings with } \\
\text { callus }\end{array}$} & \multicolumn{4}{|c|}{$\begin{array}{l}\text { \# of survived cuttings without } \\
\text { callus }\end{array}$} & \multicolumn{4}{|c|}{$\begin{array}{l}\text { \# of survived cuttings with } \\
\text { roots }\end{array}$} \\
\hline & $v_{1}$ & $v_{2}$ & $\mathbf{v}_{3}$ & Mean & $\mathbf{v}_{1}$ & $\mathbf{v}_{2}$ & $v_{3}$ & Mean & $\mathbf{v}_{1}$ & $v_{2}$ & $v_{3}$ & Mean & $v_{1}$ & $v_{2}$ & $v_{3}$ & Mean \\
\hline SWI & 1 & I & I & I & 0 & 0 & 0 & 0 & 1 & 0 & 1 & 0.66 & 0 & 1 & 0 & 0.33 \\
\hline SW2 & I & 3 & 2 & 2 & 0 & 1 & 0 & 0.33 & 1 & 0 & 0 & 0.33 & 0 & 2 & 2 & 1.33 \\
\hline SW3 & I & 2 & I & 1.3 & 1 & 0 & 0 & 0.33 & 0 & I & I & 0.66 & 0 & 1 & 0 & 0.33 \\
\hline SW4 & I & I & I & I & 0 & 0 & 0 & 0 & 1 & I & I & I & 0 & 0 & 0 & 0 \\
\hline SW5 & I & I & 1 & I & 0 & 0 & 0 & 0 & 1 & I & 0 & 0.66 & 0 & 0 & I & 0.33 \\
\hline SW6 & I & I & I & I & 0 & 0 & 0 & 0 & 1 & I & 0 & 0.66 & 0 & 0 & 0 & 0 \\
\hline SW7 & I & I & I & I & 0 & 0 & 0 & 0 & I & I & I & I & 0 & 0 & 0 & 0 \\
\hline Mean & I & 1.4 & I.I & 1.2 & 0.14 & 0.14 & 0 & 0.09 & 0.85 & 0.75 & 0.55 & 0.71 & 0 & 0.55 & 0.42 & $0.7 I$ \\
\hline
\end{tabular}

$\mathrm{VI}$, Megaron; $\mathrm{V} 2$, Chettoi; $\mathrm{V} 3$, Arbequina

SWI, 0 dSm-I; SW2, 4 dSm-I;SW3, 6 dSm-I; SW4, 8 dSm-I; SW5, 10 dSm-I;SW6, 12 dSm-I; SW7, I 4 dSm-I

Number of survived cuttings with callus is also an important parameter to assess the survival of cuttings. Saline water@4d $4 \mathrm{Sm}^{-1}$ and $6 \mathrm{dSm}^{-1}$ got similar and better performance than other saline water applications. Megaron and Chettoi olive varieties attained the similar and more number of survived in olive cutting than other variety. The use of cell and callus culture helps to focus on the physiological and biochemical mechanism, which help plant tolerance to stress. In the first spring experiment cutting forming callus percentage was generally elevated. High proportion i.e. $81 \%$ average was developed callus among three groups of cuttings (with leaves and buds, with leaves and without leaves and buds) but the group without leaves but $62 \%$ of cuttings with callus reached only with buds. ${ }^{59}$ Number of survived cuttings without callus showed the highest and similar number by Saline water@8 $8 \mathrm{dSm}^{-1}$ and $14 \mathrm{dSm}^{-1}$. Megaron olive cuttings survived better than other two olive varieties in number of survived cuttings without callus. However, number of cuttings survived with roots under saline water irrigation is the most important character to screen the olive cultivars at certain level of saline water. Saline water@4 $4 \mathrm{dSm}^{-1}$ showed the highest number of olive cutting survival (1.33) among other saline water levels. Chettoi olive cultivar produced more olive 
cuttings than other two cultivars. Soil physicochemical parameters are highly sensitive to roots. ${ }^{59}$ ROS such as singlet oxygen, superoxide, hydrogen peroxide, and hydroxyl radicals under abiotic stress can generate. ${ }^{60,61}$ The removing capacity of the antioxidant system cause important oxidative damage to proteins, lipids, and photosynthetic pigments as well as inactivation of photosynthetic enzymes when exceeds accumulation of ROS. ${ }^{62}$

\section{Acknowledgments}

This work is supported financially by the University Ibn Zohr. We are grateful to DPA (Zagoura) and farmers in Rasmouka for their substantial help in collecting the watermelon landraces.

\section{Conflicts of interest}

The author declares there is no conflicts of interest.

\section{References}

1. Shanker AK, Venkateswarlu B. Abiotic stress in plants-mechanisms and adaptations. In: TechJaneza Trdine. Croatia; 2011.

2. Vorasoot N, Songsri P, Akkasaeng C, et al. Effect of water stress on yield and agronomic characters of peanut. Songklanakarin J Sci Technol. 2003;25:283-288.

3. Kaur G, Kumar S, Nayyar H, et al. Cold stress injury during the podfilling phase in chickpea (Cicer arietinum L.): effects on quantitative and qualitative components of seeds. J Agron Crop Sci. 2008;194(6):457-464

4. Ahmad P, Jaleel CA, Salem MA, et al. Roles of enzymatic and nonenzymatic antioxidants in plants during abiotic stress. Crit Rev Biotechnol. 2010;30:161-175.

5. Thakur P, Kumar S, Malik JA, et al. Cold stress effects on reproductive development in grain crops: an overview. Environ Exp Bot. 2010;67(3):429443.

6. Mantri N, Patade V, Penna S, et al. Abiotic stress responses in plants: present and future. In: Ahmad P, Prasad MNV, editors. Abiotic stress responses in plants: metabolism, productivity and sustainability. Springer. 2012;1-19.

7. Ahmad P, Hakeem KR, Kumar A, et al. Salt induced changes in photosynthetic activity and oxidative defense system of three cultivars of mustard (Brassica juncea L.). Afr J Biotechnol. 2012;11:2694-2703.

8. Munns R. Genes and salt tolerance: bringing them together. New Phytol. 2005;167(3):645-663.

9. Zhu JK. Plant salt tolerance. Trends Plant Sci. 2001;6(2):66-71.

10. Gao JP, Chao DY, Lin HX. Understanding abiotic stress tolerance mechanisms: recent studies on stress response in rice. $J$ Integr Plant Biol. 2007;49:742-750.

11. Witcombe JR, Hollington PA, Howarth CJ, et al. Breeding for abiotic stresses for sustainable agriculture. Philos. 2008 363(1492):703-716.

12. IPCC (Intergovernmental Panel on Climate Change). Climate change 2007: the physical sciencebasis (Summary for policy makers). IPPC Secretariat,WMO, Geneva, Switzerland; 2007;21.

13. Wassmann F, Hien NX, Hoanh CT, et al. Sea level rise affecting the Vietnamese Mekong Delta: water elevation in the flood season and implications for rice production. Climate Change. 2004;66:89-107.

14. Melloul A, Collin M. Hydrogeological changes in coastal aquifers due to sea level rise. Ocean Coastal Management. 2006; 49(5-6):281-297.

15. FAO. FAO Land and plant nutrition management service. 2010.
16. Rengasamy P. Soil processes affecting crop production in salt affected soils. Funct Plant Biol. 2010;37:613-620.

17. Wild A. Soils, land and food: managing the land during the twenty-fi rst century. Cambridge University Press, Cambridge, UK; 2003.

18. http://www.ars.usda.gov/Services/docs.htm?docid=8908

19. Verslues PE, Agarwal M, Katiyar AS, et al. Methods and concepts in quantifying resistance to drought, salt and freezing, abiotic stresses that affect plant water status. Plant J. 2006;45:523-539.

20. Flowers TJ, Colmer TD. Salinity tolerance in halophytes. New Phytol. 2008;179:945-963.

21. Rahnama A, Poustini K, Munns R, et al. Stomatal conductance as a screen for osmotic stress tolerance in durum wheat growing in saline soil. Funct Plant Biol. 2010;37:255-263.

22. Munns R. Comparative physiology of salt and water stress. Plant Cell Environ. 2002;25:239-250.

23. Asch F, Dingkuhn M, Dörffl ing $\mathrm{K}$, et al. Leaf $\mathrm{K}+/ \mathrm{Na}+$ ratio predicts salinity induced yield loss in irrigated rice. Euphytica. 2000;113:109-118.

24. Haq TU, Gorham J, Akhtar J, et al. Dynamic quantitative trait loci for salt stress components on chromosome 1 of rice. Funct Plant Biol. 2010;37:634-645.

25. Munns R, James RA. Screening methods for salinity tolerance: a case study with tetraploid wheat. Plant Soil. 2003;253(1):201-218.

26. Cuin TA, Tian Y, Betts SA, et al. Ionic relations and osmotic adjustment in durum and bread wheat under saline conditions. Funct Plant Biol. 2009;36:110-119.

27. Cuin TA, Parsons D, Shabala S. Wheat cultivars can be screened for salinity tolerance by measuring leaf chlorophyll content and shoot sap potassium. Funct Plant Biol. 2010;37:255-263.

28. Garthwaite AJ, von Bothmer R, Colmer TD. Salt tolerance in wild Hordeum species is associated with restricted entry of $\mathrm{Na}+$ and $\mathrm{Cl}-$ into the shoots. J Exp Bot. 2005;56:2365-2378.

29. Shavrukov Y, Gupta NK, Miyazaki J, et al. HvNax3 -a locus controlling shoot sodium exclusion derived from wild barley (Hordeum vulgare ssp. spontaneum). Funct Integr Genomics. 2010;10:277-291.

30. Colmer TD, Flowers TJ, Munns R. Use of wild relatives to improve salt tolerance in wheat. $J$ Exp Bot. 2006;57(5):1059-1078

31. Colmer TD, Munns R, Flowers TJ. Improving salt tolerance of wheat and barley: future prospects. Aust J Exp Agric. 2005; 45:1425-1443.

32. Ismail AM, Heuer S, Thomson MJ, et al. Genetic and genomic approaches to develop rice germplasm for problem soils. Plant Mol Biol. 2007;65(4):547-570.

33. Shani, U, Ben-Gal A, Tripler E, et al. Plant response to the soil environment: an analytical model integrating yield, water, soil type, and salinity. Water Resour Res. 2007;43:W08418.

34. Ben-Gal A, Borochov NH, Yermiyahu U, et al. Is osmotic potential a more appropriate property than electrical conductivity for evaluating wholeplant response to salinity?. Environ Exp Bot. 2009;65:232-237.

35. Chartzoulakis KS. Salinity and olive: growth, salt tolerance, photosynthesis and yield. Agricultural Water Management. 2005; 78:108-121.

36. Steppuhn H, van Genuchten MT, Grieve CM. Root-zone salinity: II. Indices for tolerance in agricultural crops. Crop Sci. 2005;45:221-232.

37. Ben AC, Ben Rouina B, Boukhris M. Changes in water relations, photosynthetic activity and proline accumulation in one-year-old olive trees (Olea europaea L. cv. Chemlali) in response to $\mathrm{NaCl}$ salinity. Acta 


\section{Physiol Plant. 2008;30(4):553-560.}

38. Lutts S, Kinet JM, Bouharmont J. Effects of various salts and of mannito on ion and proline accumulation in relation to osmotic adjustment in rice (oryza sativa 1.) callus cultures. J Plant Physiol. 1996;149:186-195.

39. Rus AM, Panoff M, Perez AF, et al. $\mathrm{NaCl}$ responses in tomato calli and whole plants. J Plant Physiol. 1999;155:727-733.

40. Shibli RA, Spomer LA, Smith MAL. Osmotic adjustment and growth responses of three chrysanthemum morifolium ramat. cultivars to osmotic stress induced in Vitro. J Plant Nutr. 1992;15:1373-1381.

41. Shibli RA, Suwwan MA, Eriefej KI. Response of TYLCV tolerant tomato to nacl salinity stress: vegetative growth and Nutrient uptake. Dirasat. 1998;25:89-104.

42. Shibli RA, Smith MAL. Capacity for Biocompatability assessment in tissue culture and hydroponic systems. J Plant Nutr. 1999;22:1529-1540.

43. Smith MAL, Spomer LA, Shibli RA, et al. Effect of $\mathrm{NaCl}$ salinity on miniature dwarf tomato micro-tom: ii. shoot and root growth responses, fruit production and osmotic adjustment. J Plant Nutr. 1992;15:23292341.

44. Shibli RA, Mohammad M, Abu-Ein A, et al. Growth and micronutrient acquisition of some apple varieties in response to gradual in vitro induced salinity. J Plant Nutr. 2000;23:1209-1215.

45. Pieper M, Smith MALA. Whole plant microculture selection system for kentucky bluegrass. Crop Sci. 1999;28:611-614.

46. Smith MAL, Spomer LA, Meyer MJ, et al. Non-invasive image analysis evaluation of growth during plant micropropagation. Plant Cell Tissue Organ Cult. 1989;19:91-102.

47. Smith MAL, Spomer LA, McClelland MT. Direct analysis of root zone data in a microculture system. Plant Cell Tissue Organ Cult. 1990;23:2126.

48. Chen DM, Keiper FJ, De Filippis LF. Physiological changes accompanying the induction of salt tolerance in eucalyptus microcorys shoot in tissue culture. J Plant Physiol. 1998;152:555-563.

49. Sawwan J, Shibli RA, Swaidat I, et al. Phosphorus regulates osmotic potential and growth of african violet under in vitro-Induced water deficit J Plant Nutr. 2000;23:759-771.
50. Lutts S, Kinet J.M, Bouharmont J. Improvement of rice callus regeneration in the presence of NaCl. Plant Cell Tissue Organ Cult. 1999;57:3-11.

51. Tschaplinski TJ, Gebre GM, Dahl JE, et al. Growth and Solute adjustment of calli of populus clones cultured on nutrient Medium Containing Polyethylene Glycol. Can J For Res. 1995;25:1425-1433.

52. Morgan JM. Osomregulation and Water Stress in Higher Plants. Annu. Rev Plant Physiol. 1984;35:299-319.

53. Vieira dos Santos CL, Caldeira G. Comparative responses of helianthus annuus plants and calli exposed to $\mathrm{NaCl}$ : I. growth rate and osmotic regulation in intact plant and calli. J Plant Physiol. 1999;155(6):769-777.

54. Vigo C, Therios IN, Bosabalidis M. Plant growth, nutrient concentration, and leaf anatomy of olive plants irrigated with diluted seawater. $J$ Plant Nutr. 2005;28:1001-1021.

55. Zhu JK. Plant salt stress. Encylcopedia of Life Sciences. 2007.

56. Yadav S, Irfan M, Ahmad A, Hayat S. Causes of salinity and plant manifestations to salt stress: A review. J Environ Biol. 2011;32(5):667-685.

57. Kijne JW. Abiotic stress and water scarcity: identifying and resolving conflicts from plant level to global level. Field Crops Res. 2006;97(1):318.

58. Shekafandeh A, Sirooeenejad S, Alsmoushtaghi E. Influence of gibberellin on increasing of sodium chloride tolerance via some morpho-physiological changes in two olive cultivars. Agriculturae Conspectus Scientificus. 2018;82(4):367-373

59. Porras Soriano A, Soriano-Martín ML, Porras-Piedra A. Arbuscular mycorrhizal fungi increased growth, nutrient uptake and tolerance to salinity in olive trees under nursery conditions. Journal of Plant Physiology. 2009;166(13):1350-1359.

60. Elstner EF. Oxygen activation and oxygen toxicity. Annual Review of Plant Physiology. 1982;33:73-96.

61. Asada K. The water-water cycle in chloroplasts: scavenging of active oxygens and dissipation of excess photons. Annual Review of Plant Biology. 1999;50:601-639.

62. Bacelar EA, Santos DL, Moutinho Pereira JM, et al. Immediate responses and adaptative strategies of three olive cultivars under contrasting water availability regimes: changes on structure and chemical composition of foliage and oxidative damage. Plant Science. 2006;170(3):596-605. 